\title{
Directions of the Region Transport Infrastructure Development in the Context of Its Competitiveness
}

\author{
Vakhitova T.M. \\ Kazan Federal University, Institute of Management, Economics and Finance, Kazan, 420008, Russia
}

Gadelshina L.A.

Kazan Federal University, Institute of Management, Economics and Finance, Kazan, 420008, Russia Email address: Igadelshina@yandex.ru.

Doi:10.5901/mjss.2014.v5n24p313

\begin{abstract}
The influence of transport factors on the dynamics of regional competitiveness and the integrity of the country economic space is considered in the article. The assessment of transport factors influence allows identifying the priority directions of modernization of the Russia regional transport segments and developing a system of organizational and economic tools to increase its effectiveness and external regional competitiveness.
\end{abstract}

Keywords: transport infrastructure, passenger turnover, cargo turnover, competitiveness, the regional economy

\section{Introduction}

In the context of economic globalization the transport infrastructure has become one of the main instruments of economic development of the country and its regions. On the one hand it provides mobility of resources and products which were produced in it, on the other hand facilitates areas access allowing the free shipping of goods and passengers. Low technical level and the poor state of the transport infrastructure leads to a significant transport component appreciation in the cost of goods up to $15-20 \%$,increase in the average fuel consumption of 1.5 times, growth of the vehicles maintenance cost in 2.5-3.4 times and finally average shipping speed reduces 3-5 times. Under these conditions, the poor state of the transport infrastructure leads to a significant restriction of territories social and economic development $[1,6]$. In view of this important direction of region economic development is the need to create economic conditions and mechanisms to upgrade the transport infrastructure and the fullest realization of its potential. In other words, one needs such level of the transport infrastructure development that would provide job manufacturing industries with optimal cost and the greatest economic benefit to the region's economy increasing its competitiveness. One of the results of the transport infrastructure development will be effective transportation and logistics service which allows providing the most efficient and high-quality transport service of the region needs. [3, 4, 7]

Geographical and economic position of Russia and its partners in the Customs Union is responsible for their huge transit potential which is not completely used. One of the main reasons for under-utilization of the transit potential of the continent is a low competitiveness of the transport infrastructure, the inability to ensure the quality of transit traffic between the two macro-regions of the continent.

Such existing barriers as nonconformity of roads to the international quality standards, poor transportation infrastructure and network of logistics centers, causeless delay in control cargo weight at border crossings and so on lead to significant delays in transport. A waste of time it's not just lost money and the trust of customers, but also the loss of the main competitive advantage of land transit to maritime transport.

\section{Regional Transport Infrastructure and the Directions of Its Modernization}

An important direction of a competitive transport and logistics system development in the country and its regions is based on the integration of advanced logistics technology of all participants in the supply chain, serving the Russian regions, as well as international transport corridors passing through the territory of Russia. [2] In the medium term the formation of its own competitive regional transport and logistics infrastructure will be carried out through the creation of transport and 
logistics cluster. One of such examples is the largest logistics center of federal significance Sviyazhsk interregional multimodal logistics center which is located at the intersection of international transport corridors "North-South" and "West-East" with access to federal highways of water, rail and road posts. This center is a pilot project which is implemented in one of the subjects of the Russian Federation, in the Republic of Tatarstan and it is intended for federal cargo flows processing as existing international transport corridors "Transsib" and "North-South" and now creating international transport route "Europe-Western China." Additional attraction of cargo flows will ensure further expansion and development of new terminals of warehouse distribution network, which will lead to a redistribution of transit traffic between Europe and Asia and the logistics center will give an international status. The project will ensure the implementation of modern transport logistics principles, development of transport services export, improving the competitiveness of Russian carriers, maximum use of market potential in the field of cargo traffic. Sviyazhsk center, in the long term, can become the transport and logistics system core of cargo traffic in the Volga region of Russia.

Tatarstan was not randomly chosen as an experimental platform. It has quite an extensive transport network and transport links with all its surrounding Russia regions. [10] This is due to the complexity of the territorial structure of the region and, above all, the hierarchy of the transport network, which is characterized by stacking of intercity, suburban and long-distance transport networks, the length of the region, which determines the long distance of intra-regional traffic. The key role in the implementation of these links is not operated by railways but highways and that is not typical for the region of central Russia. Significant fact is that the length of federal highways in the country $(1,080 \mathrm{~km})$ exceeds the length of railways $(825 \mathrm{~km})$. The reason is that the construction of railways was carried out on the territory of modern Tatarstan before the main contemporary economic centers appearing. As a result the railroads do not connect directly the major cities of the country.

The contribution of the transport sector into the gross regional product is possible to estimate considering the share of the transport component in the production of goods and services of all sectors of the Tatarstan Republic economy. Thus, the total contribution of road transport component into the gross regional product of the Tatarstan Republic in 2013 was $12.3 \%$.

According to the Statistical Service of the Tatarstan Republic in January-December of 2013. companies which were engaged in road transportation of passengers of regular communication transported 276.6 million. passengers. Passenger turnover was $2,098,400,000$. passengers. The main part of public transport passenger turnover, as in the intracity as suburban and inter-city transport comes for bus transport (about $75 \%$ in the Tatarstan Republic), including long-distance transport - 67\%, suburban - 84.3\%, intracity - $619 \%$ (the end of the period). It speaks about rather dense network of highways [4].

In 2013 transport organizations of the Republic served 203,700,000. passengers, against 202.3 million. passengers for the same period in 2012 (growth of $0.6 \%$ compared to the previous year).

Also there is an increase in passenger traffic on the subway - from 3.6\% in 2009. to $6.5 \%$ in 2011., attracting a portion of the passenger traffic from traditional urban public transport as trams and trolleybuses. The volume of urban electric transport passengers in 2013 was 110.4 million passengers, compared to the same period of last year more than $5 \%$.

Railway line to the international airport "Kazan" provides intermodal functionality of airport system connecting the center of Kazan with air terminal and providing the ability to quick transfer. Transport hub "Railway station" is a major interchange point where you can carry out any kind of change to the urban passenger transport. For the carriage of passengers at this area with the length of $26.5 \mathrm{~km}$,

LLC. "Aeroexpress" involved modern electric trains Siemens Desiro Rus. However, it should be noted that there is a lack of transport accessibility of the Station Kazan-1, from this station aeroexpress goes to the airport "Kazan","The Old station" is not convenient because it doesn't have connection with the Kazan subway and in the surrounding streets there is regularly traffic jam that makes worse its availability.

According to the Ministry of Transport and Roads of the Republic of Tatarstan in 2013, overhaul and roads repair of the road network of Kazan which is the capital of the Republic of Tatarstan, was as follows: - the total number of objects - 90 , total length - $78.5 \mathrm{~km}$, the total area - 1459,766 square meters

The above data for Kazan city shows that despite the overall decline of the absolute indicator parameters of "Public transport" in the internal structure have been some shifts associated primarily with the development of the Kazan subway. Exactly here we see the growth of the rolling stock in 2013 compared to 2009, more than doubled. Also more than doubled increased the length of the route network, as for passenger traffic since 2009, in 2012 it increased by 170.3\%. In addition, during this period by $171.7 \%$ increased the number of passengers. [5]

It should be noted that in recent years in the Tatarstan Republic, a great attention was paid to the new roads construction, in particular, the construction of approach roads to the villages. For the period of 2011 to 2013 including 
Republic there were built, reconstructed and set to work 93 roads with total length of $235 \mathrm{~km}$.

Thus, on the basis of the above, one can mark out the following features of the regional transport infrastructure. Firstly, the transport infrastructure sector operates on a national scale as a single system, while its activity is characterized by a regional aspect. Secondly, there is a dominant influence result of functioning of the regional transport infrastructure on the general settings of life in the region. Third, a close relationship and interdependence of transport infrastructure with other components of the regional system is carried out. [8]

\section{Top-Priority Directions of the Regional Transport Infrastructure Development}

The main strategic direction of transport system development is balanced and integrated development of all elements of the transport infrastructure. The implementation of this strategic direction is possible while ensuring the availability, volume and competitiveness of transport services on the quality criteria for cargo owners at the level of innovative development needs of the country economy. The development of this element involves the development and implementation of the transport services market model for the needs of all economy sectors. This is an innovative model for the national transport system. It must define the parameters of the transport services quality, a framework of quality standards for different categories of goods and sectors of the economy, the requirements for the development of the legal framework in the field of transport services and engineering models to ensure the quality of transport services.

Next element of the transport infrastructure in transport development strategy is to integrate into the global transport space and realization of transit potential of the country. The development of this element involves the development of international cooperation with other international transport organizations and other Russia trade partners, expansion of participation in the system of international agreements and conventions in the field of transport, as well as in major international transport projects. Increase of Russian transport organizations participation in the transport of domestic export and import of goods as well as goods between third countries requires the development of appropriate legislative and other regulatory practices to ensure the competitiveness of the Russian transport.

Implementation of the transport system development strategy is available only on the basis of a full statistical analysis and the use of mathematical methods of forecasting needs of the economy and public in the transport services, the dynamics of cargo base and the construction of the transport system models in order to create a single transport space in Russia. [9]

Achieving this goal will ensure the dynamic growth of the state economy, socio-economic development and the strengthening of ties between its regions by removing territorial and structural imbalances on transport. However, the creation of a single transport space will give an opportunity to engage into the economic turnover new territories by creating additional transport links, increasing the competitiveness and efficiency of other industries by allowing unhindered exit of economic entities to regional and international markets, growth of business activity which directly affects the quality of life and social activity of population.

\section{Conclusions}

The position of Russia in the XXI century and the establishment of it as one of the leading centers of the multipolar world must take stand on sustainable economic development based on further economic restructuring and improving the competitiveness of domestic goods and services in the domestic and global markets, as well as full and beneficial participation in the system of labor international division. Regional and industrial monitoring of transport complex, dynamics of its development makes it possible to identify the specific features and attributes of the current state and prospects of the transport subsystem development of the Tatarstan Republic - high importance of communication links between east and west, transitive specificity, kind differentiation allowed to offer as the directions of its modernization stimulation of transport agencies and organizations innovation activities, the implementation of quality management systems, improving the efficiency of traffic management, the formation of transport and logistics infrastructure.

\section{References}

Bagautdinova N.G., Gafurov I.R., Kalenskaya N.V., Novenkova A.Z. The regional development strategy based on territorial marketing (the case of Russia) (2012) World Applied Sciences Journal 18 (Special Issue of Economics), pp. 179-184.

Gadelshina L., Vakhitova T., Shikhalev A., Ullubi S. Foreign economic and interregional relations of the Russian Federation subjects (the case of The Tatarstan Republic): analysis and predictions (2013) World Applied Sciences Journal 27 (7), pp. 939-943.

Garifova L.F., Kundakchyan R.M., Pratchenko O.V. Integrated assessment of the impact of socio-ecological-economic factors on the 
quality of life of the population of the region (2014) Mediterranean Journal of Social Sciences, pp. 117-121.

Khadaroo, J., \& Seetanah, B. (2008). Transport infrastructure and foreign direct investment. Journal of International Development, 22(1), pp. 103-123.

Panasyuk M.V., Pudovik E.M., Sabirova M.E.. 2013. Optimization of regional passenger bus traffic network // Procedia Economic and finance. Volume 5, pp. 589-596.

Safiullin L.N., Ismagilova G.N., Safiullin N.Z., Bagautdinova N.G. The development of welfare theory in conditions of changes in the quality of goods and services (2012) World Applied Sciences Journal 18 (Special Issue of Economics), pp. 144-149.

Safiullina A.M., Ivanov M.E., Ramazanov A.V. The Forms and the Methods of State Influence on the Innovation Climate Factors (On The Example of the Russian Federation and the Tatarstan Republic) (2014) Mediterranean Journal of Social Sciences. Vol. 5, № 18.

Stambrook, David. OECD Publishing (2006). Key factors driving the future demand of surface Transport Infrastructure and Services in Infrastructure to 2030: Telecom, Land Transport, Water and Electricity.

Thisse J. Analyse mathématique pour l'économie. Topologie. Paris, Dalloz, 1976 (with L.-A. Gérard-Varet and M. Prévot).

Vakhitova T., Gadelshina L., Grigorieva L. Evaluation of the relationship between integration processes and socio-economic development of regions of Russian Federation under conditions of economic globalization (Based on the Republic of Tatarstan Example) (2014) Mediterranean Journal of Social Sciences, pp. 98-103. 